\title{
Populism and the double liberalism: exploring the links
}

\section{Christian Joppke ${ }^{1}$}

Accepted: 27 January 2021/ Published online: 15 March 2021

(C) The Author(s) 2021

\begin{abstract}
The rise of populism in the West is often depicted as opposition to a "double liberalism", which is economic and cultural in tandem. In this optic, neoliberalism and multiculturalism are allied under a common liberal regime that prescribes "openness", while populism rallies against both under the flag of "closure". This paper questions the central assumptions of this scenario: first, that neoliberalism and multiculturalism are allies; and, secondly, that populism is equally opposed to neoliberalism and to multiculturalism. With respect to the alliance hypothesis, it is argued that only a diluted version of multiculturalism, in terms of diversity and antidiscrimination, is compatible with neoliberalism, which also needs to be sharply distinguished from liberalism. With respect to the dual opposition hypothesis, it is argued that the economic inequalities generated by neoliberalism may objectively condition populist revolts, but that these inequalities are not centrally apprehended and addressed in their programs; furthermore, it is argued that the rejection of multiculturalism indeed is central to populist mobilization, but that the two have important things in common, not least that both are variants of identity politics, if incompatible ones.
\end{abstract}

Keywords Liberalism $\cdot$ Multiculturalism $\cdot$ Nationalism $\cdot$ Neoliberalism $\cdot$ Populism

It has often been overlooked that multiculturalism and neoliberalism are historical twins. Both arrived jointly after the short moment in postwar Western history, ca. 1945-1975, when capitalism and democracy seemed happily reconciled in the tax-andspend welfare state and a surrounding Social Democratic consensus. Certainly, some left-liberal critics of multiculturalism noticed from early on the simultaneous rise of multiculturalism and neoliberalism, and they blamed the foregrounding of culture and "recognition" for the loss of attention to socioeconomics and "redistribution", whereby the field was left to the neoliberals and their dismantling of Social Democracy (for

Christian Joppke

joppke@soz.unibe.ch

1 Institute of Sociology, University of Bern, Bern, Switzerland 
some classic statements, see Fraser 1995 and Barry 2000). But only contemporary populism, which had its breakthrough in the West with the 2016 Brexit referendum and the ascent of Trump, has brought this coincidence into full view. Interestingly, the new vista opened up by the rise of populism is not only one of a happenstance constellation between multiculturalism and neoliberalism, one force (multiculturalism) inadvertently clearing the field for the other (neoliberalism) in a world of narrow attention spans, but of a full-blown sociopolitical alliance between both. Nancy Fraser (2017) best expressed this new perspective in her pithy notion of "progressive neoliberalism", which in her view was knocked-down by the "reactionary populism" of Donald Trump in 2016.

Indeed, a prominent academic account of contemporary populism in Western Europe and the United States is in terms of an opposition to a hegemonic "double liberalism" (Koppetsch 2019:83; Koschorke 2018; Reckwitz 2017 and 2019), the "economic liberalism" of neoliberals and the "cultural liberalism" of multiculturalists. ${ }^{1}$ In this view, multiculturalism is not the oppositional or minority force as which it likes to depict itself but pillar of the dominant political regime. In the most complete such analysis, German social theorist Andreas Reckwitz (2019) sees neoliberalism and multiculturalism united in terms of a "liberalism of openness" (apertistischer Liberalismus). Adhering to a post1970s "dynamization paradigm" (Dynamisierungparadigma), which has replaced the "regulation paradigm" of Social Democracy, the new liberalism prescribes the "general deregulation, dynamization and opening of previously fixed societal structures" (ibid. 262). As the Social Democratic left has dissipated in the transition, or its Third Way remains have shifted sides toward the forces of opening and deregulation, ${ }^{2}$ the new grand opposition to the liberal regime is right-wing populism, which pushes for national re-regulation and closure, both with respect to economics and to culture (ibid. 280). Hence we arrive at the prominent notion of a "new political divide" of "closed v. open" having overlaid or even supplanted the old "right v. left" divide. ${ }^{3}$

Interestingly, populists see it much the same way. While speaking less in terms of politics and ideology than of class and social structure, Alexander Gauland, leader of the right-wing populist Alternative für Deutschland (AfD), sees his own and other populisms, be they right or left, as fundamental opposition to a "new urban elite" that has gained strength after the end of the Cold War and in the course of globalization. ${ }^{4}$ For Gauland, the enemy is a "new class" constituted across sectors, of "people from business, politics, and the entertainment and culture industry-above all the new species of digital information workers"- the same group that is also central to Reckwitz's "cultural capitalism" analysis (2017, 2019). The shared feature of the new class is to be highly educated, cosmopolitan and dissociated from their national societies, easily switching jobs and habitat between Berlin, London and Singapore, and they mingle in the same "social but culturally diverse milieu". The "rain that falls in their home countries does not make them wet", the German populist memorably sums

\footnotetext{
${ }^{1}$ Of course, not all understandings or conceptions of multiculturalism are liberal, and many liberals (most acidly Barry 2000) have criticized multiculturalism precisely for being illiberal. For overviews of multiculturalism theories, "liberal", "communitarian", and "radical", see Joppke (2017a:ch.2; 2020).

${ }^{2}$ For a blasting critique of the neoliberalized left, based on the example of the US Democratic Party since the early 1990s, see Frank (2016). With a focus on the US New Democrats`simultaneous pandering to minority identity politics, see Lilla (2017).

3 "The new political divide", The Economist, 30 July 2016, p.7.

${ }^{4}$ Alexander Gauland, "Warum muss es Populismus sein?” Frankfurter Allgemeine Zeitung, 6 October 2018.
} 
up the privileged situation of the "globalist class". The old left-right distinction is deemed irrelevant in this constellation. The opposition to the globalist class, says Gauland, a former Christian Democrat, "could be of the right or left, but populist it has to be. To be populist means to be against the establishment". 5

The tale of the two liberalisms merged into one and of its populist Fundamentalopposition, though shared by social theorists and populists alike, slights important nuances, frictions, and incompatibilities of its constitutive elements and of their linkages. To bring them to light is the purpose of this paper. In particular, I will ask three questions. First, are multiculturalism and neoliberalism really allies, which is the central claim of the "double liberalism" tale? Secondly, is populism really an opposition to neoliberalism, the first plank of the stipulated double liberalism? And, thirdly, is populism really an opposition to multiculturalism, which is this liberalism's second plank?

The point of this exercise is not to question the legitimacy of what in the GermanEuropean tradition is called Gesellschaftstheorie, the macroscopic, diagnostic, and often critical theory of entire societies, in whose context the tale of the two liberalisms and of its populist opposition has been developed by Reckwitz and others. In Reckwitz's grand scenario $(2017,2019)$, the double liberalism tale is even only one, the political element of a large-scale vision of "late modernity" as individualized "society of singularities", which is obsessed with the cultural production and "curation" of the "singular individual", and which has also other, socioeconomic and cultural elements that are equally laid out in his theory. For such purpose, it must be allowed to make bold statements at a high level of abstraction. The specialist will naturally object that "populism", "neoliberalism", or "multiculturalism", about each of which specific and complex literatures have evolved across a variety of disciplines, are never the same in any two places or points in time; and she will conclude that juxtaposing them as holistic entities or even actors, writ large, as if each of them were one, is unduly simplifying and wrong. In addition, what each of these paired entities is, is also dependent on what other entity it is paired with, and what specific attributes of the other are highlighted. The problem is that these specialist literatures (on populism, neoliberalism, multiculturalism) are often not aware of one another, and it is precisely the advantage of higher-level templates, like that of the "double liberalism" and its forms of conflict, to bring them together and detect connections, but also inconsistencies and problems in each, that one otherwise could not see. Accordingly, it is in the spirit of refining, not of demolishing theoretical abstraction that this paper sets out "exploring the links" between three central sociopolitical phenomena of our time.

\section{Are multiculturalism and neoliberalism really allies?}

If one holds the view that multiculturalism is a matter of extending liberal democracy to minorities, the most pronounced and influential version of which is Kymlicka's acclaimed Multicultural citizenship (1995), it is a most improbable claim that multiculturalism and neoliberalism could ever be "allies". Consider that, as economic policy, neoliberalism had first been practiced by the Pinochet military dictatorship in Chile in

\footnotetext{
${ }^{5}$ Ibid.
} 
the early 1970s. This points to the uncomfortable truth that, since its invention in the pages of Friedrich Hayek, neoliberalism has been hostile to democracy. Neoliberalism is liberalism minus democracy, and in this sense not "liberal" at all, if one follows Stephen Holmes' (1995) compelling case, made with the help of the liberal classics, that liberalism requires democracy. ${ }^{6}$ Alarmed by the democratic roots of early twentieth century totalitarian rule, Hayek feared that democracy was a Trojan horse to destroy a free market society, it opened up the "road to serfdom", to quote the title of his most famous work (Hayek 1944). Historian Adam Tooze is right that "neoliberalism is... an anti-democratic politics, which resolves the tension between capitalism and democracy either by limiting the range of democratic discretion or by interfering directly in the democratic process" (quoted by Anderson 2019:90).

Neoliberalism's breakthrough in Western core states was still by democratic means, in terms of the election victories of Thatcher in the UK in 1979 and of Reagan in the US in 1980. Neoliberalism is no capitalist conspiracy, as one might think when reading its powerful indictments by Colin Crouch (2011) or Wolfgang Streeck (2013). Instead, it has been installed and perpetuated by public acclamation, in the meantime also outside its Anglo-Saxon homeland. ${ }^{7}$ Why the middle classes that mostly came to be harmed by it voted for and continued to support neoliberalism, is an intriguing question that has less often been asked than how capitalists deployed neoliberal precepts to reinstate their class power after the three-decade-long "shotgun marriage" between capitalism and democracy, post-WWII (Streeck 2016:2). An important part of the puzzle is that through (modest) asset ownership, particularly home-owning, ordinary people acquired a stake in the system. "Homevoters" are conservative, as Margaret Thatcher shrewdly realized and exploited to her great advantage - the Tories`1980 Housing Act allowed one million council flats to be bought by their working-class and lower-middle-class tenants well below market price, thus creating a "property-owning democracy" that helped keep her in office over three consecutive elections (Mau 2015:62).

One sees, the one constant in the early political realization of neoliberalism is its close association with the political right and with nationalism - for this period, Michael Mann is right to see neoliberalism "only in alliance with a conservative revival" (2013:130). For the element of nationalism, remember that Thatcher adorned her neoliberal revamping of economy and state, according to which there "is no such thing as society... and people have to look for themselves first", 8 with a throaty little war against Argentine. In the United States, the advent of neoliberalism under Ronald Reagan also saw the rise of the "neocons", who combined an endorsement of unfettered

\footnotetext{
${ }^{6}$ This is not to deny that there is a large literature, going back to (a conservative reading of) Tocqueville, which stresses tensions between liberalism and democracy, to the degree that the first prioritizes "freedom" while the second rallies around "equality". For Judith Shklar, whose "liberalism of fear" belongs to the democracy-skeptical tradition, the relationship between liberalism and democracy is at best a "marriage of convenience" (1989:37).

${ }^{7}$ For an unpersuasively narrow reading of "neoliberalism", as economic policy limited to the "Anglophone Countries"and "faltering"in the new millennium, see Mann (2013:ch.6). Without endorsing the hyperbole, I find it more adequate to see neoliberalism as a new cross-sectoral governing rationale in a society of "generalized social insecurity" (Waquant 2005:4). This neoliberal governing rationale is pithily described by Wacquant (2012:66) as ,,an articulation of state, market and citizenship that harnesses the first to impose the stamp of the second onto the third".

${ }^{8}$ This line apparently was even recited at her funeral. See the post-mortem reflection by Samuel Brittan, "Thatcher was right—-there is no 'society", Financial Times, 18 April 2013.
} 
capitalism with moral conservatism and the nationalist projection of American military power abroad. The Marxist geographer David Harvey (2005:85) concluded that "the neoliberal state needs nationalism of a certain sort to survive". Also note that, on the opposite side, the Thatcherite "link (of) unfettered market forces to a defense of traditional institutions, particularly the family and the nation" implied the "severest strictures for multiculturalism" (Giddens 1999:12), as documented in the Tories`attack on the "loony left" and local council radicalism in the mid-1980s (see Joppke 1999:243-45).

However, there is little in the logic of neoliberalism that requires "traditional nationalism", as Anthony Giddens (1999:12) called neoliberalism's early political companion. Certainly, the main link is neoliberalism's contempt for democratic equality and factual endorsement of inequality, of a natural sort of hierarchy that inevitably follows from the unfettered pursuit of market freedoms. This is also the one justification to call neoliberalism "right" in political terms. On the other hand, Hayek (1982:111) rejected "nationalism" as one of the "two greatest threats to a free civilization" (the other being "socialism"), and his "liberal society" was unabashedly cosmopolitan. It notably implied "conceding to the stranger and even the foreigner the same protection of rules of just conduct which apply to the relations to the known members of one's own small group" (ibid. 88). Moreover, to "champion[] non-discrimination" (Genschel and Seelkopf 2015:239) is a core feature of the "competition state", which is the most commonly used name for the post-1970s neoliberal state - a state that "competes" for attracting globally mobile capital and market actors. In its concise description by Philipp Genschel and Laura Seekopf (ibid.), the competition state "is basically indifferent to race, religion, income, or gender, and it welcomes social, cultural, and ethnic diversity as a productive resource. Interest, not identity, keeps national society together."

Neoliberalism's cosmopolitan and nondiscriminatory edge makes it compatible with a thin multiculturalism of diversity and antidiscrimination. In fact, some of the same international organizations that have spread neoliberalism, like the World Bank, the OECD, and the European Union, have also come around in favor of multiculturalism, and not necessarily the diluted kind (see Kymlicka 2007). For instance, the World Bank makes loans to third-world states conditional on their compliance with indigenous rights; and the EU has included the respect for minority rights in its Copenhagen Criteria that need to be fulfilled for joining the club. Of course, the true multiculturalist, like Will Kymlicka, has no good thing to say about "neoliberal multiculturalism" that provides "inclusion without solidarity" (2015:21), and that celebrates the "cosmopolitan market actor who can compete effectively across state boundaries" (2013:111) while slighting justice concerns of minorities within national societies.

Whatever one thinks of it, "neoliberal multiculturalism" became politically possible and amplified through the Third Way transformation of the political left. Epitomized by Tony Blair's Labour Party in the UK and Bill Clinton's Democratic Party in the US, the Third Way left embraced neoliberal globalization and multiculturalism in tandem. As for neoliberalism, under Bill Clinton's stewardship, the World Trade Organization (WTO) was created in 1995 that opened the floodgate for what Dani Rodrik called "hyperglobalization", which is the subverting of democratically arrived standards of health, environmental protection, or taxing and spending for the sake of global market integration as "end in itself" (Rodrik 2011:76). And Clinton, in the appositely entitled "Personal Responsibility and Work Opportunity Reconciliation Act" (1996), ended 
"welfare as we know it", initiating the turn to austere workfare that is a central element of neoliberal social policy (for early overviews, see Gilbert 2002 and Handler 2004). As for multiculturalism, Clinton famously praised his first cabinet as "look(ing) more like America than any previous", that is, including women and minorities - only forgetting to mention that they were all elite-university graduates, like himself. Under his reign, the Democratic Party gave in to the alliance of minority identity politics and Wall Street that is the hallmark of "progressive neoliberalism" (Fraser 2017). Here is a vignette from his wife Hillary's progressive-neoliberal campaign in 2016: "If we broke up the big banks tomorrow', she shouted, 'would that end racism?' 'No!' her audience replied. 'Would that end 'sexism'? 'No!' And on she went, razzing the crowd up with a pro-big bank message couched as something very different" (Shaxson 2018: ch.5).

A similar story could be told about New Labour under Tony Blair. As for neoliberalism, Margaret Thatcher famously remarked that "her greatest achievement" was "Tony Blair and New Labour. We forced our opponents to change their minds". 9 As for multiculturalism, under the label of "Cool Britannia", it became something like official state policy during Blair's first term in office, with the British Airways fleet repainted in Rastafari colors, until the twin pincer of domestic race unrest and Islamist terrorism moved the compass toward centrist "social cohesion" and "citizenship" during Blair's second term.

The epitome of the political left's neoliberal conversion is the famous Schröder-Blair Paper of June 1999, which also demonstrates neoliberalism's growing cachet beyond the Anglo-Saxon core countries. Reread 20 years later, in light of Social Democracy's near-extinction in the meantime, this paper exhibits an astoundingly naïve and drumming commitment to "economic dynamization and the freeing of creativity and innovation", while assuming that this new goal could simply be added on to the classic "social justice" agenda of the left, without any risk of incoherence or conflict. In reality, whenever a justice-minded position of old is mentioned, it is in distorted and negative form, as something to take distance from- "equality of results", the state as "replacement of the economy", a "disproportionate expansion of administration and bureaucracy", "rights without duties", "deficit spending" and the "steering of the economy to create growth and employment", the last two being the only non-distorted description of a classic Social Democratic position: all this was to be dropped in favor of "own effort and responsibility", "a new entrepreneurial spirit at all levels of society", "flexibility", and a new "supply-side agenda for the Left" that does not tolerate "excessive state indebtedness". 10 Insisting that the "first priority must be investment in human and social capital", ${ }^{11}$ and that non-economic goals like environmental protection are, of course, good for "open(ing) new markets and creat(ing) employment", the Blair-Schröder paper reads like a caricature of "neoliberal rationality", as acidly dissected by Wendy Brown (2015). It embraces the economization of everything, despite the hopeful and utterly misleading statement that the "two past decades of neoliberal laisser-faire are over". ${ }^{12}$

\footnotetext{
${ }^{9}$ See https://economicsociology.org/2018/03/19/thatcherisms-greatest-achievement/.

${ }^{10}$ Schröder-Blair Paper, "Der Weg nach vorne für Europas Sozialdemokraten", 8 June 1999, London (retrieved from http://www.glasnost.de/pol/schroederblair.html); at p.4.

${ }^{11}$ Ibid., p.6.

12 Ibid., p.4.
} 
It is obvious that the "multiculturalism" added to this neoliberal agenda, in principle, can only be of a diluted kind, deprived of its original impulse to provide justice to minorities. This is patently visible in the concept of "diversity", which is a widely used and accepted follow-up term to "multiculturalism", which has been discredited in many places, especially in Europe (see Joppke 2017a:56-60). Two chroniclers think that diversity is "the term now meant to do much of the work that 'multiculturalism' used to" (Vertovec and Wessendorf 2009:28). While true at one level, this is also misleading if one looks closer. Diversity first appeared as a legal term to repudiate an asymmetric, substantive interpretation of American civil rights law, known as "affirmative action", which was to provide justice to historically wronged minority groups, above all the descendants of African slaves. Instead, the new "diversity" idiom, first enunciated in Justice Powell's famous swing-vote opinion in the Supreme Court's seminal Regents of the University of California v. Bakke (1978) decision, couched American society in the history-distorting colors of a symmetric "nation of minorities". ${ }^{13}$ In this picture, even the white "majority" is in reality composed of a variety of "minorities" that had suffered at one point in time. Bakke incidentally saved a diluted form of affirmative action, as not entailing quotas, but under its "diversity" rationale it is largely shorn of justice elements. ${ }^{14}$ Instead, diversity is in the interest of sector-specific efficiency wherever it may appear, from business to academia or the public sector at large-diversity "straddles many worlds", as Thomas Faist put it appositely (2009:173). In the corporate world, for instance, diversity quickly became a dominant management philosophy, led by the diction that "a more diverse workforce will...bring greater access to new segments of the marketplace" (Kelly and Dobbin 1998:962).

Closely connected to diversity, antidiscrimination is a second angle for a justicedeprived, thin version of multiculturalism to become allied with neoliberalism. The relationship between multiculturalism and antidiscrimination is complex. If antidiscrimination is substantively understood as justice for minorities, it is fully compatible with, even springs from a classic multicultural agenda-however, outside of Canada, this is not the dominant legal understanding of antidiscrimination today (see Joppke 2021). The original impetus of the mother of all antidiscrimination laws, which is the 1960s US civil rights laws, was indeed to restore justice to the historical victim groups of American nation-building, above all blacks. Though arising and mostly operating in a different sector, higher education, American multiculturalism had the exact same impetus (see Glazer 1997; for the early convergence of antidiscrimination and multiculturalism in the US, see also Joppke 1996:456-465). This is not denying the opposite thrusts of antidiscrimination and multiculturalism: universalistic v. particularistic. In the US, the project of antidiscrimination, at least in the original civil rights laws, is (or was) to destroy race as a marker of discrimination; by contrast, the project of multiculturalism, from the beginning and up to its latest incarnations, was (or is) to acknowledge race as a marker of identity. For a while, both met in the middle, in terms of affirmative action, which is a radicalized, necessarily group-recognizing and thus "multicultural"

\footnotetext{
${ }^{13}$ Regents of the University of California v. Bakke, 438 U.S. 265 (1978); at 292.

${ }^{14}$ It must be conceded that the Supreme Court's Bakke decision contains a whole welter of opinions, in some of which - as in Chief Justice Brennan's concurring opinion, which was supported by three other justices-the justice element is still prominent: "Government may take race into account when it acts not to demean or insult any racial group, but to remedy disadvantages cast on minorities by past racial prejudice" (ibid., at 325). I owe this qualification to Rogers Brubaker.
} 
variant of fighting discrimination. Heavily embattled since the late 1970 s, because of the "reverse discrimination" that it entails for the non-victim group, whites, affirmative action has been reduced to the consideration of "diversity" as an optional "plus" factor, as Justice Powell put it in Bakke (1978), ${ }^{15}$ among other factors, particularly in the domain where it always mattered most: admission to university. In the process, traceable, in the domain of higher education, in the evolving Supreme Court jurisdiction from Bakke (1978) to Grutter v. Bollinger (2003) and Schuette v. Coalition v. Coalition to Defend Affirmative Action (2014), a formalistic and symmetric understanding of antidiscrimination prevailed, which prohibits negative and positive classifications on the basis of race (and other ascriptive markers), and which is not limited to historical victim groups but includes whites. While this did not happen without a fight in the US, ${ }^{16}$ a formalistic take on antidiscrimination never had a serious competitor in Europe, ${ }^{17}$ not least because of the absence of a historical victim group analogous to American blacks, which might have pushed antidiscrimination into a substantive justice direction.

The parallel between a formalistic and symmetric understanding of antidiscrimination and neoliberalism has never been explicitly drawn. However, to the degree that neoliberalism is a shrunk "liberalism" that explicitly eschews social justice, as in Hayek (1982), this parallel is too obvious to be overlooked.

If diversity and antidiscrimination are the main vehicles to build the alliance between multiculturalism and neoliberalism, its "multiculturalism" part apparently has questionable credentials. It is therefore all the more wondrous what mighty effects have been attributed to multiculturalism in the "double liberalism" tale. For Andreas Reckwitz (2019), the multiculturalist "left liberalism" and its "politics of subjective rights" has done nothing less than fuel segregation and the rise of "parallel societies". This bloated charge is curiously similar to populist demonology. "The liberal politics of multiculturalism has contributed to the cultural disintegration of immigration societies", it has favored the "self-insulation of cultural communities on the basis of ethnicity and religion", argues Reckwitz (ibid. 273). Perhaps, an illiberal, group-mongering version of multiculturalism, which does exist in activist circles but is nowhere official state practice in the Western world, may lead to such an outcome. But to hold the "liberal politics of multiculturalism" (ibid.), say, from the pages of Will Kymlicka (1995) or as it is empirically practiced in Canada or Australia, responsible for such an imagined

\footnotetext{
15 Ibid., at $311 \mathrm{f}$.

${ }^{16}$ For instance, in the domain of US employment law, starting with the federal court cases Garcia v. Gloor (1980) and Rogers v. American Airlines (1981), there has been a movement to protect ethnic, racial, and later also sexual-preference identities, and not only biologically fixed immutable markers, on the basis of Title VII of the 1964 Civil Rights Act. But this movement has largely failed (see Joppke, 2017a:136-40; 2021). Its failure in the legal domain is not to say that a substantive understanding of antidiscrimination has not been persistently dominant at the level of activist claims-making, with considerable (if highly questionable, from a liberal perspective) successes on American college campuses (in terms of free-speech restrictions in favor of "vulnerable" minority groups, and many other debatable measures) (see the critical account by Lukianoff and Haidt 2018). In the wake of the recent Black Lives Matter movement, but also of an increasingly viral LGBT rights movement, a substantive understanding of antidiscrimination has become hegemonic in public-political discourse, to the point that even moderate dissent is denounced as "racist" and "homophobic". For a rather alarmist argument that, in the US, this development should be grounded in the de facto "rival constitution" of the 1964 Civil Rights Act that now "commands the near-unanimous endorsement of judicial elites and civic educators", see Caldwell 2020 (quoted at p.6).

${ }^{17}$ A certain exception to this are women. See Joppke (2021), and also the helpful contrasting of the different trajectories of antidiscrimination in Europe and the United States by De Búrca (2012).
} 
outcome (which "immigration society" is actually "culturally disintegrated", and how would we know?), is patently absurd. Relatedly, it is simply not correct to say that the "liberal politics of subjective rights", arguably the beating heart of liberal multiculturalism, "is helpless to work against the process of disintegration" (Reckwitz 2019:275). Liberal law does have all the necessary tools to counteract "disintegration", such as the public order principle and its proportionality and balancing tests, according to which no subjective right is ever absolute. A closer look into the evolving Islam file of European high courts, allows no other conclusion (see Joppke and Torpey 2013). The equation of a liberalism of subjective rights with extremer forms of multicultural identity politics, and of both with cultural disintegration and the rise of "parallel societies", is a canard that should be put to rest.

\section{Populism v. neoliberalism?}

Perhaps the most compelling aspect of the tale of the two liberalisms is that it sidesteps a sterile controversy in the explanation of contemporary populism, with one strand arguing in favor of an economic, and another in favor of a cultural explanation, as if the two were not connected or complementary. An influential opinion survey of Inglehart and Norris (2016), for instance, slices up the field this way - and then argues in favor of a "cultural backlash" over an "economic have-not" explanation of populism. In reality, both economics and culture matter as explanatory factors. This sounds trivial but needs to be underscored. And, of course, politics matters, too, as a third, and perhaps crucial dimension for any account of "populism" stricto sensu. This is because populism, underneath its variegated expressions, left or right, socialist or nationalist, is always a response to a presumed democracy deficit, juxtaposing an unaccountable and corrupt "elite" and a homogenous and pristine "people" who notionally should rule in a "democracy" but are heinously deprived of their constitutive power by unresponsive and rent-seeking elites (the centrality of politics for any explanation of populism is the important message of Pappas 2019).

With respect to the controversial economics v. culture distinction, both factors matter but they matter in different ways. Growing economic inequality, which is a signature feature of societies undergoing neoliberal globalization, functions more as an objective background factor, operating a tergo by feeding a sense of stagnation and fear of the future among large portions of the Western lower middle classes. By contrast, as scores of analyses of the programs of populist radical right parties and of their supporters' views have demonstrated, culture and way of life issues, the resurrection of a denigrated "majority" against the onslaught by uppity "minorities", tend to be foregrounded. "(C)ulture has trumped economics as the singular feature of the radical right", argued one of the first (and still best) analyses of the fast-growing new family of radical right parties in Europe (Art 2011:11). In his analysis of the "coming of age" of populism, in terms of Brexit and Trump, David Goodhart (2017:2) agrees. He interprets both as the result of "unhappy white working class voters (plagued) more by cultural loss, related to immigration and ethnic change, than by economic calculation." Note that in the above quoted auto-analysis of German populist Gauland, the one word that appears most often is "Heimat" (home), which is claimed by "ordinary people" as a "value in itself", above all against "immigrants" who "stream into their 
neighborhoods": "They cannot just move away and play golf somewhere else"18 (unlike The Donald, he might have added).

While the relationship between populism and democracy is contested, some finding populism an expression of democracy (Canovan 1999 or Mény and Surel 2002) while others see it as threat to democracy (Müller 2016), no single analysis has ever questioned that populism is gutturally opposed to liberalism. "Democratic illiberalism" thus is appositely the politics-centered "minimal definition" of populism proposed by Takis Pappas (2019:35): "Populism is always democratic but never liberal". Cas Mudde (2004:561) concurs in a near-identical and widely influential description of populism as "illiberal democracy", which "rejects all limitations on the expression of the general will, most notably the constitutional protection of minorities and the independence... of key state institutions."

However, how neoliberalism fits into this picture is much less clear. At the level of theory and of policy alike, there is a compelling case for neoliberalism to be distinct from liberalism. Certainly, both share the centrality of the individual and her liberties in the constitution of social and political order. However, neoliberalism parts ways with liberalism in its categorical denial of social justice. "Social justice", as neoliberalism's chief theorist Friedrich Hayek (1982:99) put it dismissively, is "dislike of people who are better off than oneself, or simply envy". Hayek's denial of social justice as task for public policy is not part of the classical "liberal idea", as masterfully retold by Stephen Holmes, according to which there is a "fundamental continuity between liberal rights and welfare rights" (1995:266). In lieu of social justice, neoliberalism advocates a harshly individualistic understanding of "responsibility" and "responsibilization", which shows in post-welfarist "responsibility-tracking" social policies, like workfare programs (see Mounk 2017: ch.2). In the terms of the canonic late-twentieth century version of liberalism, by John Rawls (1971), neoliberalism condones "equal liberty", Rawls' first principle of justice, yes; but neoliberalism emphatically denies Rawls' second justice principle, the "difference principle", which tolerates inequality only to the degree that it helps the worst-off in society, and thus is a case for redistribution to further social justice.

In plain terms, neoliberalism advocates unfettered market freedoms, "market fundamentalism" as Block and Somers (2014) have called it, not in the words but in the spirit of Karl Polanyi. Neoliberalism thus understood is not just an economic policy prevailing in the "Anglos", for a while, and not much elsewhere, as argued by Michal Mann (2013: ch.6). Instead, it flags a comprehensive restructuring of the social and political order throughout the West, even shaping the way we look at the individual, not primarily as a carrier of rights, as in the liberal tradition, but as an economically fungible carrier of "human capital" (first observed by Michel Foucault [2008], and brilliantly updated by Wendy Brown [2015]).

Because neoliberalism is the main ideology undergirding contemporary globalization, it must be involved in the making of its opposition, which is populism. However, with the exception of left-wing populism in southern Europe, which has opposed the post-financial-crisis austerity policy dictated by the European Union and the IMF, "neoliberalism" is generally not found as adversary or something to rally against in the programs of populist parties in Europe. Nor can it be found in the tweets of the one-

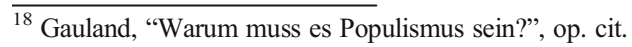


time chief-populist in power, Donald Trump, unless it could be turned into nationalist resentment, against "China" or other predators. American populism, in terms of Trump and the Tea Party movement that has supported him, is even neoliberal itself, viscerally rejecting the idea of the state as an instrument of social justice (see Hochschild 2016). In Europe, populist radical right parties also often have neoliberal roots, as does the French Front National (originating in old middle-class Poujadisme), the Freiheitliche (sic!) Partei Österreichs (FPÖ), or most recently the German AfD (which had started as a professorial anti-Euro platform) — and the most successful Western European populist party of all, the Swiss People's Party (SVP), which is Switzerland's most-voted party for over 20 years now, even continues to be stoutly neoliberal, being pro-market and anti-state.

The tale of the two liberalisms is thus wrong in depicting populism, at least in its predominant right-wing version, as self-conscious opposition to "economic liberalism", aka neoliberalism. Certainly, most of these parties and movements (with the exception of the American Tea Party and the Swiss SVP) have in the meantime adopted a prowelfare agenda, advocating an ethnically exclusive "welfare chauvinism". ${ }^{19}$ They thus fill in their role as the new working-class parties after the "Third Way" demise of the left. This turn has been particularly marked in the French Front National (now Rassemblement National), under the leadership of Marine Le Pen. But in none of the radical right party programs, including the French, does one find a detailed socioeconomic alternative to the neoliberal hegemony, as astutely observed by Claus Offe (2019:376). This is much in contrast to these parties detailed positioning on the "multicultural" issues of immigration, Islam, or sexual morals.

Even though contemporary right-wing populism may not self-consciously address and foreground its economic background factors, they are nevertheless operative. Reviewing a century of "populist revolts" in America and Europe, economic historian Barry Eichengreen noted that these revolts "rarely arise in good economic times" (2018:x). Tellingly, at the height of postwar prosperity, the period fondly remembered in France as the Trentes Glorieuses, there was no populism in Europe and America. Its rise coincides with the breakup of the postwar class consensus and the rise of neoliberalism, first, and globalization, a decade later, the two becoming intricately linked as the liberation of markets, especially for finance, from territorial state controls. The sociodemographic basis of Western populism is located between the 75th and 90th income percentile on economist Branko Milanovic's famous "elephant curve" (2012), which shows relative per capita income gains between 1988 and 2008 at all points of the global income distribution. The people in this bracket, though globally rich, have seen their net incomes stagnate or even fall in this period, which is the period of globalization. This global income bracket is mostly filled by the Western lower middle classes, who are thus the proverbial losers of globalization.

Importantly, the Western lower middle classes are relative losers of globalization, particularly in comparison with the richest $1 \%$ who have seen their income and wealth explode like perhaps never before in human history. Opponents of an economic explanation of the rise of right-wing populism in the West point out that it is not the very poor or the unemployed who typically support such parties or movements, and instead they point to their strong middle-class support and its cultural anguish.

\footnotetext{
${ }^{19}$ The to date best analysis of (the limits of) ethnically „selective solidarity“ is Koning (2019), which compares Sweden, Canada, and the Netherlands.
} 
However, this is beside the point, because - as Tocqueville was the first to notice and Karl Polanyi also was acutely aware of - a relative loss may be even more painfully experienced than an absolute loss.

In an important analysis of the US case, Daniel Markovits (2019) correctly notes that, considering a dramatically declined income-poverty rate over the past half-century, from over $40 \%$ in 1945 to just under $5 \%$, economic inequality today is "driven overwhelmingly not by poverty but by concentrated wealth" (ibid. 102). Previously, the rupture in American society was between a broad middle to upper class with no clear distinction between the two (dubbed the "great compression"), on the one hand, and a great number of poor people, on the other. By contrast, the "new rupture" is between the "rich" running away from the rest and a middle class whose income gap separating them from the poor has narrowed: "(T)he poor/middle-class income gap has narrowed by about a quarter since midcentury, while the middle-class/rich income gap has nearly doubled" (ibid. 105). In this sense, "rising high-end and falling low-end inequality occur together" (ibid. 98).

However, Markovits ' (2019) main point is not this. Rather, it is that the major generator and transmitter of growing economic inequality is meritocracy. This helps explain why neoliberalism is so difficult to oppose, by populists and others, because meritocratic inequality is ipso facto "just" or "deserved". In a counterpoint to Thomas Piketty's famous claim that the main source of economic inequality today are fastgrowing gains from capital (2014), Markovits argues that the rich are rich because they work and exploit their own human capital, typically boosted by a degree from an elite university. In his calculation, "perhaps two-thirds or even three-quarters" of the total income of the top $1 \%$ of earners in the US is drawn from "their labor and therefore... their education" (2019:13). However, unlike in Michael Young's famous fable that had invented the very word "meritocracy" (1959), this is not a natural meritocracy, based on inborn talent, in Young's dystopian scenario identified and separated from the rest shortly after birth. Instead, it is a social meritocracy based on "more and more intense cultivation of nurtured talent, extending longer and longer" (Markovits 2019:259). It is a "sham" meritocracy that launders pre-existing economic inequality through the "feedback loops", on the one side, of dual-career families having become breeding sites of human capital and, on the other side, of technological workplace innovations being made by and mainly for the "superordinate working class"; as a result of the latter, there are only "gloomy" or "glossy" jobs, while middle-tier jobs are about to disappear (for the new "gig" or "platform" economy that shows exactly this dual and polarized job profile, see also Crouch 2019).

The middle class, this is Markovits' (2019) somber message, is categorically excluded from the self-reproductive and closed meritocracy of the rich, in which money is converted into skills and skills are converted back into more money. For Markovits, the meritocratic regime is a variant of the "resource curse" breeding autocratic elite rule, which previously had been associated with the oil-rich "rentier states" of the Middle East. The resource curse works much the same with human capital: "The feedback loops between exclusive education and skill-based innovation entrench and expand the elite's privilege and shrink and marginalize the middle class" (ibid. 257).

In Young's fable (1959), meritocracy falls in a bloody upheaval by "populists" what remarkable foresight! However, it is not quite clear how this upheaval is possible because, by Young's own argument, the devious power of meritocracy, where social 
position mirrors individual desert, is to deprive the lower classes of "a distinctive ideology in conflict with the ethos of society" (ibid. 124): "For the first time in human history the inferior man has no ready buttress for his self-regard" (ibid. 108). The same paradox permeates Markovits' real-world account (2019: ch.3). According to it, meritocracy does breed a new "class war", as is to be expected in a situation of "comprehensively isolated social classes", coexisting on the same territory like Disraeli's "two nations" in Victorian England. But it is a "class war" that does not dare to speak its name, because the very class nature of meritocracy is systematically concealed. Those who lose out, as Markovits sharply observes, are "victims without a language of victimhood" (ibid. 63). Accordingly, while sparing the meritocracy principle itself, the losers get high on meritocracy's rejection of ascriptive discrimination. A meritocracy, one must know, is naturally inclusive of immigrants and other minorities - they, more than any other group, prove that you can make it against the odds. Accordingly, a meritocracy is "excessively sensitive to...prejudice that has no meritocratic glossbased on race, ethnicity, gender, or sexuality" (ibid. 60); this is a "cardinal and unforgivable sin that must be suppressed absolutely and without regard for the cost" (ibid.). In a nutshell, "the meritocratic fixation on diversity and inclusion channels the anger into nativist, sexist identity politics" (ibid. 64). The losing "majority" copies the language of the "minorities" who are courted by meritocracy: "Rising nativist assertions of white, male, heterosexual, or Christian identities...follow inexorably from meritocratic inequality's economic structure and ideological limitation" (ibid. 63). But then we are in the domain of culture and identity politics, away from the economic inequalities that are still the root cause of the underlying resentment. Factoring in meritocracy allows us to explain how and why economic grievance becomes articulated in cultural terms, which is a central feature of right-wing populism in the West. This realistically supplants an earlier version of cultural backlash politics by or on behalf of disadvantaged whites, which had rallied around the claim of "reverse discrimination" constituted by minority-privileging affirmative action (the main claim by Allan Bakke, a white male, in the famous 1978 Supreme Court named after him). This earlier backlash had still, if only implicitly, defended classic meritocratic principles like standardized admissions tests for college and universities, also as more adequate path for minority "assimilation". 20

When fleshing out the "selective moralism" of meritocracy's disdain for discrimination, Markovits (2019:61) further observes that "(p)olitical correctness does not denounce calling rural communities 'backward', southerners 'rednecks', Appalachians 'white trash', and the bulk of the United States 'flyover country '". ${ }^{21}$ Importantly, the disparaging signifiers all point to place-based identities. This is yet another reason why the economic bases of populism often go misrecognized: the economic inequalities generated by globalization are inherently connected to place. Globalization privileges cities, because human capital only flourishes when put to work in proximity to its own kind (see Florida 2003). In turn, human capital is being serviced by a predominantly immigrant underclass, which yields the "sand hour" stratification typical of "global cities" (see Sassen 1991).

\footnotetext{
$\overline{20}$ This earlier backlash was conjoined by an (auto-)critique of minority assimilation impaired by a groupmongering "ethos of entitlement", fed by measures like bilingual education, affirmative action, and minority set-asides in federal contracts. See Chavez (1991).

${ }^{21}$ As one can read in the introduction of J.D. Vance's memoir, Hillbilly Elegy (2016): "Americans call them hillbillies, rednecks, or white trash. I call them neighbors, friends and family.“
} 
The combined effect of globalization is to disadvantage the countryside, so that resentment against it must be concentrated there (see Cramer 2016).

In a global survey of populist revolts in developing and developed countries, from Thailand to France, economic geographer Andrés Rodriguez-Pose (2017) has pointed out that not "interpersonal inequality", as highlighted in the celebrated work of Thomas Piketty (2014), but "territorial inequality" has been key to all of these revolts. Populism is "revenge of the 'places that don't matter"' (Rodriguez-Pose 2017:5): "Populist votes have been heavily concentrated in territories that have suffered long-term declines and reflect an increasing urban/regional divide" (ibid. 18). The evidence for this abounds. The Brexit vote was concentrated in industrial and disadvantaged rural areas of the North and East of England; Lincolnshire, the county with the highest share of the Brexit vote, has been among the areas with the lowest GDP growth over the past quarter century. ${ }^{22}$ And Trump won due to tiny margins in traditionally Democrat "rustbelt states" like Ohio and Pennsylvania. But even here, big cities, like Pittsburgh and Cleveland, all went for his Democratic opponent. It is thus the combination of "rustbelt and flyover country" that breeds populism. In France, it is much the same story. In none of its big cities did Le Pen win the largest share of the presidential votes in 2017. Instead, she prevailed in medium-sized and small cities and rural areas of the French rustbelt in the North and North-East, like Champagne-Ardenne, Franche-Comté, Lorraine, Nord-Pas-de-Calais (now including the Picardie). And also here the larger cities, like Metz, Nancy, Reims, and Lille (in the second election round) went for her nonpopulist contender, Emmanuel Macron's En Marche. Again, the combination of "rustbelt and flyover country" is decisive. Hence the strong middle-class component in populist parties and movements, which consists of the provincial bourgeoisies that have not yet actually lost out but are in fear of losing out under globalization. ${ }^{23}$ In sum, an increasingly place-based inequality under contemporary globalization is yet another factor that hides from view the economic underpinnings of populism.

\section{Populism v. multiculturalism?}

In the tale of the double liberalism, populism is as categorically opposed to multiculturalism as it is opposed to neoliberalism. We qualified this with respect to neoliberalism, which operates a tergo but is rarely (if at all) subjectively apprehended as the enemy to beat. Because contemporary right-wing populism mainly addresses cultural issues and appears in the form of nativism and nationalism, its self-conscious opposition to multiculturalism is much more obvious. Some have even argued that opposition to multiculturalism is constitutive of populism. Francis Fukuyama (2018:118), most prominently, has argued that multicultural identity politics has "stimulated the rise of identity politics on the right", and he identified two plausible mechanisms for this connection. The first is that multicultural identity politics gives rise to "political correctness, opposition to which has become a major

\footnotetext{
$\overline{22}$ Philip Manow's (2018:130) "economic geography of populism“" confirms that the June 2016 pro-Brexit votes were concentrated in "backward" regions.

${ }^{23}$ Representative for many analyses, see Bergmann et al. (2017), who wittily describe the German AfD, which is strongest in the provincial east of Germany, as the party of "(sich) $a$ usgeliefert fühlende Durchschnittsverdiener" (average earners who feel victimized) - note that the first letters in German yield the acronym $A f D$.
} 
source of mobilization on the right" (ibid.). And the second is that the "idea that my particular group is being victimized" (ibid. 122) can be easily adopted by majority groups, not least due to their demographically and politically imperiled situation in many Western immigrant societies (for evidence, see Orgad 2015: ch.1 and 2).

However, calling both multiculturalism and populism a "politics of identity", also suggests some communalities that merit further attention. First it needs to be underscored that populism is best understood as "political style" (Moffitt and Tormey 2014) or "stylistic repertoire" (Brubaker 2017:363), because it can be filled with a variety of political content, right or left, nationalist or socialist. Against this backdrop, populism in the West today is mainly (but not exclusively) of the right-wing and the nationalist kind. Yet, if one probes deeper into the nature of this nationalism, it resembles in many ways the multiculturalism that is notionally opposed by it.

To the degree that there is a coherent doctrine underlying nationalist populism, it resembles what the French New Right intellectual, Alain de Benoist, has called "ethnopluralism". This doctrine, which has been highly influential in radical right circles, also outside France, is akin to a groupist, non-liberal version of multiculturalism. One could call it multiculturalism appropriated by the majority group. Ethnopluralism's main tenet is the "equivalency of homogenous peoples in their indigenous territories" (De Benoist, quoted by Weiss 2017: ch.1). Importantly, it notionally repudiates "racism" because of the latter's rejection of human variety and hierarchizing of races (De Benoist 2017:56, 86). However, ethnopluralism shares with classic racism its antiindividualism, the unconditional subsuming of the individual and of her capacities and character to the presumed features of the origin group; and it shares with racism the assumption that, for the sake of purity, a mixing of ethnic or racial groups is to be avoided at all cost. Yet, and here the similarity with multiculturalism kicks in, ethnopluralism differs from classic racism in shifting the basis of ethnicity or race from biology to culture, and in eschewing the notion of a hierarchy of groups in favor of their equality-the New Right endorses the "variety" of the world's cultures and of the groups that carry them (ibid. 30). This sounds much like multiculturalism, at least a groupessentializing variant of it. The rightist element shows in the axiomatic rejection of egalitarianism in favor of inequality and hierarchy, which self-defines the New Right qua "Right". The resulting stance is inconsistent and contradictory because inequality is repudiated between groups while it is endorsed within groups.

Ethnopluralism's key assumption is the denial of shared humanity in favor of prior group membership. This yields a right-wing version of radical multiculturalism whose group-protecting point of reference is not minorities but the majority (see Spektorowski 2003). Ethnopluralism, in fact, explicitly borrows from multiculturalism the "right to difference", but it moves its point of reference from minorities to the majority and thus turns the right to difference into the rejection of intra-state diversity, in the extreme, into the call for ejecting the minorities. Of course, Algerian or Moroccan-origin Muslims have the right to be different, but only in their own territories. Similarly, the answer to "Black Power" is "White Power". De Benoist, (2017:103) calls it "mutual decolonization": "What is good for the Bororos or the Guaqaquis should...also 
be good for us...Let us affirm the right of peoples to be just themselves; the right of all peoples to fully develop themselves, against any kind of universalism and against all racisms."24

An admirably iconoclastic proposal to bridge the majority-minority divide, not in rightist- but leftist-multiculturalist terms, has been made by Eric Kaufmann (2018:1). He argues in favor of a "symmetrical multiculturalism" in which "white identity" is recognized and protected as "an ethnic identity like any other". It is premised on the ultraliberal idea of a strictly neutral state, not claimable by a majority, but which "de-center(s) itself from the ethnic majority and treat(s) it as just another stakeholder" (ibid. 524).

The problem with a majority-inclusive, "symmetrical multiculturalism" is the assumption that "white" or "majority" identity could be like any other identity, adjudicated by a neutral state that "doesn't play favourites, but must carry out its duty to represent the cultural interests of its stakeholder communities" (Kaufmann 2018:523). One wonders: who would run this state from nowhere, a new "gelded" elite, to assure impartiality (as known in some agrarian societies, see Gellner 1981:14-5)? ${ }^{25}$

The question is: can there be a legitimate "white identity" politics, as is Kaufmann's (2018) claim? Another way of posing the question is to ask whether the "myths of descent, symbols and traditions", which is Kaufmann's (ibid. 1) description of the content of "ethnic identity", could ever be innocent, that is, non-racist, in the particular case of "white". It is difficult to come up with an affirmative answer. Kaufmann slights the distinction between racial and ethnic. "White" is a racial, not ethnic marker. If we follow Max Weber's (1976:234) classic understanding of "race membership", it is primarily defined by a negative demarcation from the "conspicuously different" (auffällig Andersgeartete). Unlike ethnicity, Weber seems to suggest, race is not in the first a positive and self-defined marker, but it is always pejorative and a discriminatory intention by others is constitutive of it. The matter is further complicated by the fact that "whites" have been on the beneficiary end of a racial hierarchy that it itself has brought into existence, at great cost to the other "races".

That a positive and non-discriminatory "white identity" is nevertheless possible, is the provocative empirical claim of a recent survey analysis of the United States (Jardina 2019). The Trump phenomenon, indeed, has usually been explained in terms of "white identity politics", though in the standardly negative and discriminatory variant. On the contrary, Duke sociologist Ashley Jardina suggests, "(m)any whites identify with their racial group, without feeling prejudice toward racial and ethnic minorities" (ibid. 5). According to her in-depth analysis of a broad swathe of opinion data, 30-40\% of the white population in the US is "high on racial solidarity", but the "vast majority" of

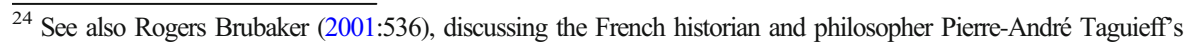
analysis of the French New Right, whose "differentialist" discourse was adopted by Le Pen's National Front: "(F)ormally 'heterophile', antiracist, and egalitarian, the new differentialists of the right emphasized, indeed absolutized, cultural difference... 'Droit à la différence? Mais oui, bien sûr, chez vous'. But here, in France - so went the argument - it's we, the 'real' French, who have their own right to be different..."

25 This problem also mars Alan Patten's (2014) attempt to find the "moral foundations" of multicultural minority rights in the idea of a perfectly neutral state. Kymlicka (1995) is more realistic in this respect, arguing that, in matters of national majority culture, "benign neglect" is not possible, thus advocating the co-existence of liberal nationalism and liberal multiculturalism. That "benign neglect" may not even be possible in matters of religion, which was still assumed by Kymlicka (1995), is argued, in starkly exaggerated fashion in my view, by "critical secularism" studies in the mold of Talal Asad (most incisively, Mahmood 2016; for a critique, see Joppke 2017b).
} 
them also "reject white supremacy and racism" (ibid. 8). These positive race identifiers, she argues, simply favor policies that are in their group interest, like social security, Medicare, or legacy college admissions. ${ }^{26}$ At the same time, these whites are indifferent and not hostile to minority-favoring policies like affirmative action or Medicaid (ibid. ch.7). Jardina concludes that "we must...think about white identity in the way we think of black identity" (ibid. 34), or of any group identity studied within socialpsychological "social identity theory". "Racial identity" is simply "a conscious favoritism for one's in-group and recognition that one's group has shared interests" (ibid. 47-8).

Somewhat dissonant with this assumption of a basic symmetry between minority and majority identities, which she shares with Kaufmann (2018), is Jardina's unavoidable concession that in the case of "whites" we are dealing with "dominant group identity", which is actualized by the realistic "threat" of becoming a numerical minority by mid-century (2019:42). If one probes further into this "dominance", "white" immediately loses its innocence and it can no longer be just another "group identity". One would have to be amnesic about the problematic past of "whites" as America's Herrenrasse (master race), reigning and protecting itself through Jim Crow segregation and racially discriminatory immigration policies well into the mid-twentieth century, to find dignity in it today. Moreover, the very fact that "so many white Americans (were) drawn to a candidate like Donald Trump, who was often derisive of racial and ethnic minorities" (ibid. 3), suggests that the boundaries between in-group favoritism and outgroup hostility must be more porous than Jardina would have it.

In sum, while both minority and majority may dwell in "identity politics", the attempts to reconcile them within a symmetrical multiculturalism (Kaufmann 2018) or within an ordinary ethnic politics paradigm (Jardina 2019), must fail.

\section{Doubts, and where to go from there}

The tale of the double liberalism, neoliberal and multicultural in tandem, which is countered by the Fundamentalopposition of right-wing populism, is a widely shared diagnosis of the contemporary political divide in the West, closely overlapping with the assumption that "open v. closed" is overlaying and modifying the old "left v. right" cleavage.

As this paper tried to demonstrate, the relationship between the constitutive elements of this scenario: populism, neoliberalism, and multiculturalism, is less clear-cut and more intricate than first meets the eye. The core assumption of the double liberalism tale, that there is an alliance of sorts between neoliberalism and multiculturalism, is on shaky grounds. Apart from the problem that the "liberalism" pedigree of neoliberalism is questionable, only a thin version of multiculturalism, in terms of diversity and antidiscrimination, is compatible with a neoliberalism whose defining mark is an austere individualism and rejection of the idea of social justice. With respect to the

\footnotetext{
${ }^{26}$ As Rogers Brubaker remarked in a commentary on a previous draft of this paper, the beneficiaries of Social Security and Medicare certainly are not exclusively "whites", while legacy college admissions should be in the interest of only a small portion of them. To Jardina's defense, she only looks at what is perceived by and not what is in the interest of "whites".
} 
stipulated opposition between populism and neoliberalism, there seems to be an objective conditioning of populism by the widening wealth gap and the creeping middle-class erosion that go along with neoliberalism. This neoliberalism and its economic bases, however, tend not to be apprehended and addressed by populist actors. Instead, cultural issues, in particular, the vindication of majority culture over that of the minorities, centrally preoccupy the latter. Accordingly, the stipulated opposition of populism to multiculturalism is on firmer ground. However, there are subterraneous communalities between the populists` nationalism and multiculturalism, which I tried to demonstrate in the discussion of "ethnopluralism" and of "white identity politics". These communalities still don't warrant the construct of a majorityinclusive, symmetrical multiculturalism or application of an ordinary ethnic politics paradigm.

All three central terms of this paper: populism, neoliberalism, and multiculturalism, are problematic because they are not just "categories of analysis" but, and primarily, "categories of practice" (Brubaker 2012), and heavily polemicized practical categories at that. The notions of "populism" and "neoliberalism" have in common to be mostly external designations by theorists or political actors who dislike both; self-designated "populists" or "neoliberals" are thin on the ground. Similar problems plague the concept of "multiculturalism", the perhaps most enigmatic of the three, which Stuart Hall once called "maddeningly spongy and imprecise" (quoted in Koopmans 2013:148). Vagueness and indeterminacy reigns whenever the term is used, in the world of practice even more than in the world of theory. For the world of practice, just consider the EU. On the website of the European Commission's Migration and Home Affairs Unit, ${ }^{27}$ one finds this definition of "multiculturalism": "A policy that endorses the principle of cultural diversity and supports the right of different cultural and ethnic groups to retain distinctive cultural identities ensuring their equitable access to society, encompassing constitutional principles and commonly shared values prevailing in the society." This is a notably friendly because liberal-inclusive definition of multiculturalism, which closely aligns it with "constitutional principles" and "shared values"what is exactly denied by those opposed to it, from some liberals to populists. But then, under "synonym(s)", the EU document lists "interculturalism". This is arguably wrong, because this concept has evolved as a centrist critique of an allegedly differencemongering multiculturalism (see Zapata-Barrero 2017). And, under "related term(s)", there is "cultural diversity". This is at best a half-truth, as I tried to show above. Finally, under "note(s)", the EU document mentions that "(m)ulticulturalism emphasizes cultural differences... without necessarily much contact or...interaction". This is the standard charge of "interculturalism", which thus cannot simply be a "synonym" of multiculturalism. This pejorative description of multiculturalism also contradicts the same document's initial liberal-inclusive definition of multiculturalism. One sees, confusion reigns, and probably not only in the European Commission.

If the internal meaning of our key concepts is indeterminate, also depending on which other concept(s) and aspects thereof they are paired with, so must be their relationships. The notions of "allies" and "opposition", which I used for describing the relationship between populism and the two liberalisms, suggest stance-taking by

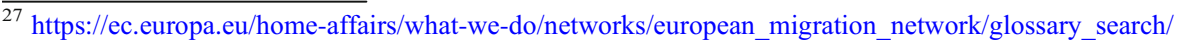
multiculturalism_en
} 
concrete socio-political actors, and whenever possible I tried to identify them-such as Third Way leftist parties as typical platform for the "alliance" between multiculturalism and neoliberalism, and radical right parties as typical "opposition" to the two. It is the translation of conceptual-level Wahlverwandtschaften (elective affinities), to use Max Weber's enigmatic term, or of frictions and incompatibilities at this level, into the concrete reality of socio-political actors and organizations, which is the biggest challenge for future work.

Just take the central assumption of an "alliance" between the two liberalisms. What does it mean exactly? This needs further exploration. Nancy Fraser's "progressive neoliberalism" (2017) suggests that such "alliance" is concretely accomplished in the post-1990s Democratic Party in the US. But hers is merely a cursory sketch that was never fully worked out (but see Frank 2016), nor has it been applied to, or systematically compared with, other countries and political systems. The most complete version of the double liberalism tale, by Andreas Reckwitz (2017 and 2019), actually speaks less in terms of "alliance" than of "political paradigm", which is at a higher level of abstraction, allowing for both alliance and opposition under the same umbrella. Importantly, in the new paradigm of the "liberalism of openness" (apertistischer Liberalismus), which is said to have replaced the old paradigm of "social corporatism", the left-right distinction is still operative, as "left liberalism" (or "cultural liberalism") pitted against "economic liberalism" on the right (2019:251). Accordingly, the "liberalism of openness" is a "synthesis of two wings (Flügel) of a new liberalism, of which one is right, the other left of the center" (ibid. 261). As a result, "at the level of actors" (Akteursebene), these "wings often distrust one another" (ibid. 262). At the same time, Reckwitz sees both poles of the new paradigm united, not so much in terms of political party than of social class: the "central carrier group" of the "liberalism of openness" is said to be the "new middle class of the highly qualified, who are concentrated in metropolitan regions and marked by high spatial mobility" (ibid.) — note that the German populist Gauland's notion of "new urban elite" (2018) had the exact same ring. Reckwitz's new middle class is "in some parts more neoliberally, in others more left-liberally oriented; partially it is also both together" (2019:262). What unites this class is not least its "common opponent", which at the level of "political paradigms" is "the now apparently rigid, freedomquashing and collectivist paradigm of social corporatism" (ibid.) - and at the level of actors and organizations, are the populists and their radical right parties.

As if life imitates art, not only one of Germany's leading populists, but also one of the country's Green Party leaders, Robert Habeck, seems to have taken his perception of current sociopolitical realities from the pages of Andreas Reckwitz (even quoting him in a recent book, Habeck 2021). Habeck depicts himself and his Green Party as representatives of the "individualistic, liberal, and cosmopolitan milieu, geared toward authenticity (Selbstverwirklichung) and the good life, which has acquired cultural hegemony in the past few decades" (ibid. 322). Now the challenge, in his view, is the forging of a new "normative center" (ibid. 318), a "new culture of communality (Gemeinsamkeit)" (ibid. 315) to overcome the populism-infested "politics of polarization" (ibid. 323). Down to the formulation, this also mirrors Reckwitz's diagnosis that in an age of economically and culturally fired "singularities", there is the need for the "constitution of something in society that is shared by all" (Konstitution eines gesellschaftlichen Allgemeinen) (2019:290). For the Green politician, the professed preoccupation with "all of society" (das gesellschaftliche Ganze) (Habeck 2021:322) and hope for a "new societal center" (ibid. 315), is a thinly concealed coalition offer to the center-right Christian Democratic Union (CDU) in the German federal 
election year 2021, as sociologist Stephan Lessenich suspects in a sarcastic review (2021). Never naming the CDU, which despite its being a Volkspartei (catch-all party) is still the main platform of Germany's business interests (especially of the entrepreneurial Mittelstand), Habeck depicts his Greens as inherently an "alliance party" (Bündnispartei), and "alliance means by definition that people of different views, background, and milieu work together" (Habeck 2021: 326). In fact, in the process of becoming Germany's secondstrongest party, after the CDU, the Greens have long shed their previous anti-capitalist edges, and they now appraise (ecologically and socially tamed) markets as "powerful instruments of economic efficiency, innovation and technological progress" (Bündnis 90The Greens 2020:19). At the same time, of course, the party of "trans" and of other multicultural things, the Greens by themselves are the "double liberalism" on legs, which would merely be doubled-down by the Green-Black coalition that may well be the next government of Germany. The Green-Black "new center" (Habeck), which might inherit the current Red-Black (SPD-CDU) coalition in swallowing the old left v. right distinction, will guarantee that populism will not disappear anytime soon.

Funding Open Access funding provided by Universität Bern.

\section{Compliance with ethical standards}

Conflict of interest The author declares that there is no conflict of interest.

Open Access This article is licensed under a Creative Commons Attribution 4.0 International License, which permits use, sharing, adaptation, distribution and reproduction in any medium or format, as long as you give appropriate credit to the original author(s) and the source, provide a link to the Creative Commons licence, and indicate if changes were made. The images or other third party material in this article are included in the article's Creative Commons licence, unless indicated otherwise in a credit line to the material. If material is not included in the article's Creative Commons licence and your intended use is not permitted by statutory regulation or exceeds the permitted use, you will need to obtain permission directly from the copyright holder. To view a copy of this licence, visit http://creativecommons.org/licenses/by/4.0/.

\section{References}

Anderson, P. (2019). Situationism à l'envers? New Left Review, 119, 47-93.

Art, D. (2011). Inside the radical right. New York: Cambridge University Press.

Barry, B. (2000). Culture and equality. Cambridge: Polity.

Bergmann, K. et al. (2017). Die AfD: Eine Partei der sich ausgeliefert fühlenden Durchschnittsverdiener. Zeitschrift für Parlamentsfragen no.1, 57-75.

Block, F., \& Somers, M. (2014). The power of market fundamentalism. Cambridge: Harvard UP.

Brown, W. (2015). Undoing the demos. New York: Zone Books.

Brubaker, R. (2001). The return of assimilation. Ethnic and Racial Studies, 24(4), 531-548.

Brubaker, R. (2012). Categories of analysis and categories of practice. Ethnic and Racial Studies, 36(1), 1-8.

Brubaker, R. (2017). Why populism? Theory and Society, 46(5), 357-385.

Bündnis 90-The Greens. (2020). `...zu achten und zu schützen... `: Veränderung schafft Halt. Grundsatzprogramm (https://www.gruene.de/artikel/das-neue-grundsatzprogramm).

Caldwell, C. (2020). The age of entitlement: America since the sixties. New York: Simon and Schuster.

Canovan, M. (1999). Trust the people! Populism and the two faces of democracy. Political Studies, 47, 2-16.

Chavez, L. (1991). Out of the barrio. New York: Basic Books.

Cramer, K. (2016). The politics of resentment. Chicago: University of Chicago Press. 
Crouch, C. (2011). The strange non-death of neoliberalism. Cambridge: Polity.

Crouch, C. (2019). Will the gig economy prevail? Cambridge: Polity.

De Benoist, A. 2017 (1985). Kulturrevolution von rechts. Dresden: Jungeuropa Verlag.

De Búrca, G. (2012). The trajectories of European and American antidiscrimination laws. American Journal of Comparative Law, 60, 1-22.

Eichengreen, B. (2018). The populist temptation. New York: Oxford University Press.

Faist, T. (2009). Diversity - A new mode of incorporation? Ethnic and Racial Studies, 32(1), 171-190.

Florida, R. (2003). Cities and the creative class. City and Community, 2(1), 3-19.

Foucault, M. (2008). The birth of biopolitics. London: Palgrave.

Frank, T. (2016). Listen, liberal! New York: Metropolitan Books.

Fraser, N. (1995). From redistribution to recognition? New Left Review, 112, 68-92.

Fraser, N. (2017). The end of progressive neoliberalism. Dissent, 2 January.

Fukuyama, F. (2018). Identity. New York: Farrar, Straus and Giroux.

Gauland, A. (2018). Warum muss es Populismus sein? Frankfurter Allgemeine Zeitung, 8 October.

Gellner, E. (1981). Nations and nationalism. Ithaca: Cornell University Press.

Genschel, P., \& Seelkopf, L. (2015). "The competition state", in S. Leibfried et al. Oxford handbook of transformations of the state. Oxford: Oxford University Press.

Giddens, A. (1999). The third way. Cambridge: Polity.

Gilbert, N. (2002). Transformation of the welfare state. New York: Oxford University Press.

Glazer, N. (1997). We are all multiculturalists now. Cambridge: Harvard University Press.

Goodhart, D. (2017). The road to somewhere. London: Hurst.

Habeck, R. (2021). Von hier an anders: Eine politische Skizze. Köln: Kiepenheuer \& Witsch.

Handler, J. (2004). Social citizenship and workfare in the United States and Western Europe. New York: Cambridge University Press.

Harvey, D. (2005). A brief history of neoliberalism. New York: Oxford University Press.

Hayek, F. (1944). The road to serfdom. Chicago: University of Chicago Press.

Hayek, F. (1982). The mirage of social justice. London: Routledge.

Hochschild, A. R. (2016). Strangers in their own land. New York: The Free Press.

Holmes, S. (1995). Passions and constraint. Chicago: University of Chicago Press.

Inglehart, R. and P. Norris. 2016. Trump, Brexit, and the rise of populism. HKS faculty research working paper RWP 16-026, Harvard Kennedy School, Cambridge, Mass.

Jardina, A. (2019). White identity politics. New York: Cambridge University Press.

Joppke, C. (1996). Multiculturalism and immigration. Theory and Society, 25(4), 449-500.

Joppke, C. (1999). Immigration and the nation-state: The United States, Germany, and Great Britain. Oxford: Oxford University Press.

Joppke, C. (2017a). Is multiculturalism dead? Crisis and persistence in the constitutional state. Cambridge: Polity.

Joppke, C. (2017b). Blaming secularism. European Journal of Sociology, 58(3), 577-589.

Joppke, C. (2020). Multiculturalism, in P. Kvisto, ed. Cambridge handbook of social theories (vol.2). New York: Cambridge University Press.

Joppke, C. (2021). Multiculturalism and antidiscrimination law: Comparing the United States and Western Europe, IDC Law Review (forthcoming).

Joppke, C., \& Torpey, J. (2013). The legal integration of Islam: A transatlantic comparison. Cambridge, Mass: Harvard University Press.

Kaufmann, E. (2018). Whiteshift. London: Allen Lane.

Kelly, I., \& Dobbin, F. (1998). How affirmative action became diversity management. American Behavioral Scientist, 41(7), 960-984.

Koning, E. A. (2019). Immigration and the politics of welfare exclusion: Selective solidarity in western democracies. Toronto: University of Toronto Press.

Koopmans, R. (2013). Multiculturalism and immigration. Annual Review of Sociology, 39, 147-169.

Koppetsch, C. (2019) Die Gesellschaft des Zorns: Rechtspopulismus im globalen Zeitalter. Bielefeld: transcript.

Koschorke, A. (2018) Auf der anderen Seite des Grabens. ZfL Blog (Leibniz-Zentrum für Literatur- und Kulturforschung, Berlin), 30 August.

Kymlicka, W. (1995). Multicultural citizenship. Oxford: Oxford University Press.

Kymlicka, W. (2007). Multicultural odysseys. New York: Oxford University Press.

Kymlicka, W. 2013. Neoliberal multiculturalism?. In P. hall and M. Lamont, Social resilience in the neoliberal era. New York: Cambridge University Press.

Kymlicka, W. (2015). Solidarity in diverse societies. Comparative Migration Studies, 3(17), 15-33.

Lessenich, S. 2021. Bleibt alles anders. Soziopolis-Newsletter (Hamburg) 18 January (https://www.soziopolis. de/lesen/buecher/artikel/bleibt-alles-anders-1/). 
Lilla, M. (2017). The once and future liberal. New York: Harper.

Lukianoff, G., \& Haidt, J. (2018). The coddling of the American mind. New York: Penguin.

Mahmood, S. (2016). Religious difference in a secular age: A minority report. Princeton, N.J: Princeton University Press.

Mann, M. 2013. The sources of social power, vol.4. Globalizations, 1945-2011. New York: Cambridge University Press.

Manow, P. (2018). Die politische Ökonomie des Populismus. Berlin: Suhrkamp.

Markovits, D. (2019). The meritocracy trap. New York: Penguin.

Mau, S. (2015). Inequality, marketization and the majority class. London: Palgrave.

Mény, Y. and Y. Surel. 2002. The constitutive ambiguity of populism, in Y. Mény and Y. Surel (eds.), Democracies and the populist challenge. Basingstoke: Macmillan.

Milanovic, B. 2012. Global income inequality by the numbers. Policy research working paper 6259, The World Bank, Washington, D.C.

Moffitt, B., \& Tormey, S. (2014). Rethinking populism. Political Studies, 62, 381-397.

Mounk, Y. (2017). The age of responsibility. Cambridge: Harvard UP.

Mudde, C. (2004). The populist zeitgeist. Government and Opposition, 39(4), 541-563.

Müller, J.-W. (2016). What is populism? Philadelphia: University of Pennsylvania Press.

Offe, C. 2019. Wille und Unwille des Volkes, in C.Offe, Liberale Demokratie und soziale Macht, vol. 4. Wiesbaden: Springer VS.

Orgad, L. (2015). The cultural defense of nations. New York: Oxford University Press.

Pappas, T. (2019). Populism and liberal democracy. Oxford: Oxford University Press.

Patten, A. (2014). Equal recognition: The moral foundations of minority rights. Princeton: Princeton University Press.

Piketty, T. (2014). Capital in the $21^{\text {st }}$ century. Cambridge: Harvard University Press.

Rawls, J. (1971). A theory of justice. Cambridge: Harvard University Press.

Reckwitz, A. (2017). Die Gesellschaft der Singularitäten. Berlin: Suhrkamp.

Reckwitz, A. (2019). Das Ende der Illusionen. Berlin: Suhrkamp.

Rodrik, D. (2011). The globalization paradox. New York: Oxford University Press.

Rodriguez-Pose, A. (2017). The revenge of the places that don't matter. Cambridge Journal of Regions. Economy and Society, 11(1), 189-209.

Sassen, S. (1991). Global cities. Princeton: Princeton University Press.

Shaxson, N. (2018). The finance curse. London: The Bodley Head.

Shklar, J. 1989. The liberalism of fear, in N. Rosenblum, ed. Liberalism and the moral life. Cambridge, Mass.: Harvard University Press.

Spektorowski, A. (2003). The new right. Journal of Political Ideologies, 8(1), 111-130.

Streeck, W. (2013). Gekaufte Zeit. Berlin: Suhrkamp.

Streeck, W. (2016). How will capitalism end? London: Verso.

Vance, J. D. (2016). Hillbilly elegy. New York: HarperCollins.

Vertovec, S. and S. Wessendorf. 2009. Assessing the multiculturalism backlash in Europe. MMG working paper 09-04, Max Planck Institute for the Study of Religious and Ethnic Diversity, Göttingen.

Waquant, L. (2005). Punishing the poor: The neoliberal government of social insecurity. Durham: Duke University Press.

Wacquant, L. (2012). Three steps to a historical anthropology of actually existing neoliberalism. Social Anthropology, 20(1), 66-79.

Weber, M. (1976). Wirtschaft und Gesellschaft. Tübingen: Mohr.

Weiss, V. (2017). Die autoritäre Revolte. Stuttgart: Klett-Cotta.

Young, M. (1959). The rise of the meritocracy 1870-2033. London: Thames and Hudson.

Zapata-Barrero, R. (2017). Interculturalism in the post-multiculturalism debate. Comparative Migration Studies, 14(5), 1-23.

Publisher's note Springer Nature remains neutral with regard to jurisdictional claims in published maps and institutional affiliations.

Christian Joppke is Professor of Sociology at the University of Bern. He has written numerous books and articles on social movements, immigration, citizenship, multiculturalism, and religion. His most recent book is Neoliberal Nationalism: Immigration and the Rise of the Populist Right (Cambridge University Press 2021). 